\title{
社会資本スピルオーバー効果の県間比較*
}

\section{Regional Propagation of the Local Social Capital Investment*}

小池 淳司**.西尾 明子***

By Atsushi KOIKE**and Akiko NISHIO***

\section{1. 背景と目的}

わが国では, 中央・地方政府の慢性的な財政悪化から公 共事業の効率化が求められている. 一方で, 地域間交易を 通じた地域間での経済的繋がりはますます強くなってき ている. このことから，国土計画的な意味において，地方 公共事業における国と地方の費用負担問題は大きな課題 の1つとなっている. そこでの議論は，地方公共事業によ りもたらされる費用と便益の違いを国土計画的な意味で の公平性と社会的効率性の観点から計測・分析することで ある.

現実問題として, 現在, 政府主導の下, 三位一体改革に よる地方分権や税源移譲が議論されている. しかしながら, 道州制導入の際の地域分割の基準を見る限り定性的なも のが大半であり, 公共事業をはじめとする政策の効果の範 囲の予測や費用対効果の評価など明確な指針となるよう な内容は見受けられない. しかしながら，一般に，地方公 共事業によって社会資本整備を行なう際, その効果は当該 地域のみならずその他の地域へも波及すると考えられて いる.

地方公共事業の効果には直接的な効果と間接的な効果 があることが知られている. 前者は社会資本を直接提供す る主体や利用する主体への影響であり発生便益とよばれ， 後者は直接効果がある一定の期間を経て直接利用しない 主体にまで帚着する効果をいい帰着便益とよばれている. ここで間接的な効果とは, 直接的には当該地域の世帯の効 用あるいは企業の効率性をあげるものであり，このような 企業の効率性の向上は, 当該地域の経済活動のみならず, 地域間交易を通じて, 他地域の生産財市場・生産要素市場 に影響を及ぼし最終的には当該地域を含め他地域の家計 の効用に影響を及ぼす。

従来から, 生産関数法りとして知られている効果計測手

*キーワーズ : 地域間スピルオーバー効果, SCGE モデル

**正員, 工博, 鳥取大学工学部社会開発システム工学科

(鳥取市湖山町南 4-101, e-mail : koike@sse.tottori-u.ac.jp) ***学生員, 鳥取大学大学院工学研究科 博士前期課程
法は,ここでいう発生便益であり, 最終的な便益の享受者 である帰着便益を地域別に知ることが出来ない.

そこで, 本研究では, このように間接効果が経済活動 (特 に，地域間交易）を通じて他地域に㛿着する便益を間接的 空間波及（スピルオーバー）効果として定量的に計測し, 比較することを目的とする. 具体的には, 社会資本整備に よる影響を考慮可能な空間的応用一般均衡 (SCGE) モデ ルを用いて，わが国の 47 都道府県ごとに社会資本整備を 行った場合の帰着便益を定量的に計測し，その結果から地 域社会費本事業による便益の空間的波及構造について分 析する.これにより都道府県ごとに帰着便益の波及構造の 違いを考察することを目的としている. 分析にあたって, モデル内では各都道府県の全要素生産性が社会資本ス卜 ックの関数であると仮定し, 社会資本投資の効果を分析す るフレームを採用している. なお, 本研究が対象としてい る社会資本の効果とは, 企業の生産性向上にのみ限定して いる.

\section{2. モデルの概略}

本研究では, 社会資本整備による間接スピルオーバー効 果を計测するモデルとして小池・上田・秋吉 2)を用いた. 想定する社会経済については以下の仮定をおく.

(1) $I$ 個に分割された国土空間を考える.

(2)各地域には、アクティビティベースの $J$ 個の企業と代表 的家計が存在する.

(3)政府が行う社会資本整備は社会資本ストックとなり, 当 該地域の企業の生産効率性を直接的に向上させる.

(4)生産財市場は地域に開放されているのに対して、生産要 素市場は地域内で閉じている. また, 地域間所得移転は 無いものとする.

(5)各財は Armington 仮定を前提としている. (6)社会経済は長期均衡状態にある.

（1）企業の行動モデル

地域 $i$ 立地し $j$ 財を生産寸る企業は, 自地域と他地域 で生産された中間投入財, (民間) 資本, 労㗢, 社会資本 
により生産される付加価值をネスティド CES 型の生産構 造で定式化する. 第 1 段階において, 企業の生産関数は以 下のようなレオンチェフ型の生産関数で定式化できる.

$$
Q_{j}^{i}=\min \left(\frac{V A_{j}^{i}\left(l_{j}^{i}, k_{j}^{i}, g^{i}\right)}{a_{0 j}^{i}}, \frac{x_{1 j}^{i}}{a_{1 j}^{i}}, \cdots, \frac{x_{j^{\prime} j}^{i}}{a_{j^{\prime} j}^{i}}, \cdots, \frac{x_{j j}^{i}}{a_{J j}^{i}}\right)
$$

ただし, $Q_{j}^{i}$ : 地域 $i$ 産業 $j$ の生産量, $V A_{j}^{i}$ : 地域 $i$ 産業 $j$ の 付加価値, $x_{j^{\prime} j}^{i}$ : 地域 $i$ の産業 $j^{\prime}$ から産業 $j$ への中間投入 合成財, $a_{j^{\prime} j}^{i}$ : 地域 $i$ の産業 $j^{\prime}$ から産業 $j$ への投入係数, $a_{0 j}^{i}$ : 地域 $i$ 産業 $j$ の付加価值比率

第 2 段階における付加価値は, 労衝之資本について規模 に関して収穫一定であるコブ・ダグラス型であると仮定す る. ここで, 社会資本ストックの整備水準は企業の全要素 生産性（あるいは, 生産効率性）に直接的に影響寸るもの と仮定し, 式(3)のように定式化する. これらの定式化よ り生産要素需要関数が導出される.

$$
\begin{aligned}
& \min w^{i} l_{j}^{i}+r^{i} k_{j}^{i} \\
& \text { s.t. } V A_{j}^{i}=\eta_{j}^{i}\left(g^{i}\right) l_{j}^{i \alpha_{j}^{i}} k_{j}^{i \alpha_{2 j}^{i}}=1 \\
& \quad \eta_{j}^{i}\left(g^{i}\right)=\mu_{j}^{i} g^{i \alpha_{j_{j}}}
\end{aligned}
$$

ただし， $w^{i}$ : 地域 $i$ の労働賃金率, $r^{i}$ : 地域 $i$ の資本レン 卜, $l_{j}^{i}$ : 地域 $i$ 産業 $j$ の労働投入量, $k_{j}^{i}$ : 地域 $i$ 産業 $j$ の 資本投入量, $g^{i}$ : 地域 $i$ 社会資本ストック量, $\eta_{j}^{i}$ : 地域 $i$ 産業 $j$ の効率パラメータ, $\alpha_{1 j}^{i}:$ 地域 $i$ 産業 $j$ の労㗢の分 配パラメータ, $\alpha_{2 j}^{i}$ : 地域 $i$ 産業 $j$ の資本の分配パラメー 夕 $\left(\alpha_{1 j}^{i}+\alpha_{2 j}^{i}=1\right), \mu_{j}^{i}$ : 地域 $i$ 産業 $j$ の生産技術の効率パ ラメータ, $\alpha_{3 j}^{i}$ : 地域 $i$ 産業 $j$ の生産技術パラメータ

第 2 段階における中間投入合成財に関しては，CES 型 で定式化し, 費用最小化行動として以下のように定式化す る. これにより各地域の中間投入需要が導出される.

$$
\begin{aligned}
& \min \sum_{i^{\prime} \in I} P_{j^{\prime}}^{i^{\prime}} x_{j^{\prime} j}^{i^{i}} \\
& \text { s.t. } \left.x_{j^{\prime} j}^{i}=\phi_{j^{\prime}}^{i}\left(\sum_{i^{\prime} \in I} \delta_{j^{\prime} j^{i}}^{i^{i} x^{i^{\prime} j} j}\right)^{\frac{\sigma-1}{\sigma}}\right)^{\frac{\sigma}{\sigma-1}}=1
\end{aligned}
$$

ただし, $P_{j}^{i}$ : 地域 $i$ 産業 $j$ の生産財価格, $x_{j^{\prime} j}^{i i}$ : 地域 $i^{\prime}$ か ら地域 $i$, 産業 $j^{\prime}$ から産業 $j$ への中間投入財, $\phi_{j^{\prime} j}^{i}$ : 地域 $i$ の産業 $j^{\prime}$ から産業 $j$ への効率パラメータ, $\delta_{j^{\prime} j}^{i^{i}}:$ 地域 $i^{\prime}$ か ら地域 $i$, 産業 $j$ から産業 $j$ への分配パラメータ, $\sigma$ : 地 域選択の代替弾力性

企業の生産関数については規模に関して收穫一定を仮 定しているため企業の超過利潤はゼロとなり,かつ生産財 価格は単位生産量あたりの生産費用 (平均費用) に等しく
なり，以下のように求めることが出来る.

$$
\begin{aligned}
P_{j}^{i}= & a_{0 j}^{i}\left(w^{i} c l_{j}^{i}+r^{i} c k_{j}^{i}\right) \\
& +\sum_{j^{\prime} \in J} a_{j^{\prime} j}^{i}\left(\phi_{j^{\prime} j}^{i}\right)^{-1}\left(\sum_{i^{\prime} \in I} \delta_{j^{\prime} j}^{i^{i} \sigma} P_{j^{\prime}}^{i^{1-\sigma}}\right)^{\frac{1}{1-\sigma}}
\end{aligned}
$$

\section{（2）家計の行動モデル}

各地域には代表的家計が存在し, 自地域と他地域の財を 消費するネスティドCES 型の効用関数構造をもつと仮定 する. 第 1 段階は, 所得制約条件下での効用最大化行動之 して以下のように定式化する.これにより, 合成消費財の 需要関数が導出される.

$$
\begin{aligned}
& V^{i}=\max \left(\sum_{j \in J}\left(\gamma_{j}^{i}\right)^{\frac{1}{\rho 1}}\left(q_{j}^{i}\right)^{\frac{\rho-1-1}{\rho 1}}\right)^{\frac{\rho l}{\rho-1}} \\
& \text { s.t. } \sum_{j \in J} p_{j}^{i} q_{j}^{i}=w^{i} L^{i}+r^{i} K^{i}
\end{aligned}
$$

ただし, $V^{i}$ : 地域 $i$ の間接効用関数, $q_{j}^{i}$ : 地域 $i$ 産業 $j$ の 合成財消費量, $L^{i}$ : 地域 $i$ の労動供給量, $K^{i}$ : 地域 $i$ の資 本供給量, $\gamma_{j}^{i}$ : 地域 $i$ での産業 $j$ からの分配パラメータ, $\rho_{1}$ : 財選択の代替弾力性, $p_{j}^{i}$ : 地域 $i$ での産業 $j$ の合成消 費財価格

第 2 段階では, 自地域生産財と他地域生産財の代替関係 を $\mathrm{CES}$ 型で定式化する. その最適化行動は以下のように なり, これにより各地域の生産財需要関数が導出される.

$$
\begin{aligned}
& V_{j}^{i}=\max \left(\sum_{i^{\prime} \in I}\left(\gamma_{j}^{i i}\right)^{\frac{1}{\rho_{2}}}\left(q_{j}^{i^{i} i}\right)^{\frac{\rho_{2}-1}{\rho_{2}}}\right)^{\frac{\rho_{2}}{\rho_{2}-1}} \\
& \text { s.t. } p_{j}^{i} q_{j}^{i}=\sum_{i^{\prime} \in I} P_{j}^{i^{i}} q_{j}^{i^{i i}}
\end{aligned}
$$

ただし, $V_{j}^{i}$ : 地域 $i$ 産業 $j$ の間接勃用関数, $q_{j}^{i i}$ : 合成財 消費量, $\gamma_{j}^{i i}$ : 地域 $i^{\prime}$ から地域 $i へ の$ 産業 $j$ の分配パラメー 夕, $\rho_{2}$ : 地域選択の代替弾力性

\section{（3）市場均衡条件}

本モデルでは, 企業の生産に対して規模に関して収穫一 定と仮定しているため, 企業は常に需要に応じた生産を行 う. そのため, 生産財市場における市場均衡条件は以下の ように常に成立し, 財価格は単位生産量あたりの費用とし て決定される.

$$
Q_{j}^{i}=\sum_{i \in I} \sum_{j \in J} x_{j^{\prime} j}^{i i}+\sum_{i \in I} c q_{j}^{i i} q_{j^{\prime}}^{i}
$$

また, 全ての生産要素市場は地域内で閉じているため, 地域 $i$ での生産要素市場での均衡式は以下のようになる.

$$
\sum_{j \in J} \alpha_{1 j}^{i} \frac{a_{0 j}^{i} Q_{j}^{i}}{w^{i}}=L^{i}
$$




$$
\sum_{j \in J} \alpha_{2 j}^{i} \frac{a_{0 j}^{i} Q_{j}^{i}}{r^{i}}=K^{i}
$$

\section{3. パラメータの設定}

まず, 空間的応用一般均衡モデルに関するパラメータは 通常のキャリブレーション手法によって設定する.ただし， 地域選択における代替弾力性および生産関数における社 会資本整備水準による技術係数は別途推計しなければな らない.

そこで, 企業と家計の財の生産地選択の代替弾力性パラ メータのうち農林水産業・製造業については土谷・秋吉・ 小池 6)で求めた代替弾力性のパラメー夕推計結果をもと に設定した（なお，推定精度に関しては原論文参照)。具 体的には，表-1 に示す 21 産業の推計結果を，平成 12 年 度全国産業連関表における各産業の総生産額を用いて加 重平均を行い，農林水産業・製造業の 2 産業についてパラ メータを算出した. 各産業の産業区分は表-2 に示すとおり である.なお, 上記以外に本研究で扱う 6 産業については, 代替弾力性の值は 1 とした. 本研究で用いる地域選択の代 替弹力性パラメータの推計值は表 3 のとおりである.

\section{表-1 既存研究によるわが国の生産地選択代替弾力性}

\begin{tabular}{l|r}
\hline \multicolumn{1}{c|}{ 産業名 } & 代替弾力性パラメータ \\
\hline 農業 & 5.24 \\
林業 & 18.22 \\
漁業 & 13.56 \\
鉱業 & 4.86 \\
食料品·たばこ & 16.25 \\
織維製品 & 17.03 \\
木材·木製品 & 14.80 \\
家具·装備品 & 10.14 \\
パルフ紙·加エ品 & 15.50 \\
新聞·印刷·製本 & 18.00 \\
化学工業製品 & 14.42 \\
石油·石炭製品 & 19.05 \\
プラスチック製品 & 30.25 \\
ゴム製品 & 13.00 \\
窯業·土石製品 & 19.39 \\
鉄䤡製品 & 12.07 \\
金属製品 & 16.72 \\
一般機械 & 5.27 \\
自動車 & 19.64 \\
輸送機械 & 32.07 \\
その他製造業 & 15.08 \\
\hline
\end{tabular}

表-2 産業区分(農林水産業·製造業のみ)

\begin{tabular}{|c|c|}
\hline 产羓区分名 & 产業名 \\
\hline 曹林水産業 & 震業,林業漁業 \\
\hline 製造業 & 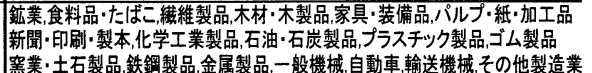 \\
\hline
\end{tabular}

表-3 本研究における地域選択の代替弾力性

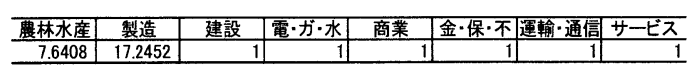

次に, 本モデルでは社会資本ストック量が企業の全生産 要素生産性（あるいは生産効率性）へ影響すると仮定する ことで財の地域間交易を通じた各都道府県への社会資本 スピルオーバー効果の把握を可能としている. しかし, 各
地域について社会資本の生産技術への影響の仕方をどの ように想定するかによって生産効率性の推計結果は異な り,これはシミュレーション結果にも反映されると考えら れる. そこで本研究では, 社会資本の生産技術への影響に ついて表-4 に示寸ような 3 つのケースの生産関数を想定 した. なお，Case2 の地域区分については表-5 のとおり である.つまり, Case1では生産関数のパラメータを全国 で, Case2 ではブロック(地域ごとで同一のものとして推 定しているのに対し, Case3 では各県ごとにパラメータを 推定している.

表-4 生産関数(生産技術)の想定

\begin{tabular}{|c|c|}
\hline & 社会資本の生産技術への影響 \\
\hline Case1 & 47都道府県全てに同じように影響する \\
\hline Case2 & ブロックで異なる (47都道府県を9ブロックに統合) \\
\hline Case3 & 都道府県で異なる \\
\hline \multicolumn{2}{|r|}{ 表-5 Case2 における地域区分 } \\
\hline 地域区分 & 対象地域(域内都道府県) \\
\hline 北海道 & 北海道 \\
\hline 東北 & 青森，岩手，宮城，秋田，山形，福島 \\
\hline 関東 & 茨城，杤木，群馬，埼玉，千萎，東京，神奈川，新渴，山梨，長野，静岡 \\
\hline 中部 & 富山，矺，岐卓，愛知，三重 \\
\hline 近畿 & 福井，滋賀，京都，大服，兵庫，奈良，和歌山 \\
\hline 中国 & 鳥取，島根，岡山，広島，山口 \\
\hline 四国 & 德島、香川，愛媛、高知 \\
\hline 无州 & 福岡，佐賀，長崎，熊本，大分，宮崎，鹿児島 \\
\hline 沖縄 & 沖縄 \\
\hline
\end{tabular}

表4の各ケースについて, 産業連関表と整合するよう付 加価值部門のデータ3)からキャリブレーションにより推計 した生産効率性パラメータ $\eta_{j}^{i}=\eta_{j}^{i}\left(g^{i}\right)$ と社会資本ストッ ク額 $g^{i} 4$ を用いて生産技術パラメータの推計をした. なお, 本研究で扱っている社会資本ストック額は公表されてい る全種類の社会資本ストックデータを統合したものを用 いている. パラメータの推計式は生産効率性に関する式 (9)を対数変換することで得られる.

$$
\ln \left[\eta_{j}^{i}\left(g^{i}\right)\right]=\ln \mu_{j}^{i}+\alpha_{3 j}^{i} \ln g^{i}
$$

上記の式より, 最小二乗法を用いて各ケースのパラメータ を産業ごとに推計した. 各ケースの想定と生産技術パラメ 一夕の推定結果は付表一 1 のとおりである. また, 実際に パラメータを決定する際には生産技術パラメータ $\alpha_{3 j}^{i} に$ 関して(1)推計結果がマイナスの值である(2)推計したパラ メータ $\alpha_{3 j}^{i}$ と $\mu_{j}^{i}$ から求まる効率性パラメー夕の推計值と 実測值の相関係数が 0.5 以下という $2 つ の$ 条件のうちどち らかを満たした場合, 社会資本はその産業の生産技術の向 上には影響を与えないと考え，生産技術パラメータ $\alpha_{3 j}^{i}$ に ついては 0 , 生産技術の効率パラメータ $\mu_{j}^{i}$ について $\mu_{j}^{i}=\eta_{j}^{i}$ とした. これは社会資本ストックと生産技術にな んらかの正の相関関係がみられる産業のみに限定して分 析を行ったことに他ならない. 


\section{4. 実証分析と考察}

実証分析として, 各都道府県の社会資本ストック額が増加 した場合の空間的波及効果を計測した. また, 基準データセ ットは平成 7 年度都道府県間産業連関表 5)を用いた. 政策シ ナリオは社会資本ストック額を基準年の状態から $10 \%$ 増加 させるとし,この政策を 47 都道府県ごとについて実施した. また, 一連のシミュレーションを上述の 3 つケースで求め た生産関数それぞれの場合について行なった. それぞれの久 一スについて各都道府県に政策を実施した場合の帰着便益 の割合をまとめたものを以下に示す.

図-1 から図-3 は各ケースについて一連のシミュレーシ ヨンを行なった場合の便益の帰着構造を示すものである. 各 グラフには政策実施都道府県ごとの便益額を政策実施地域

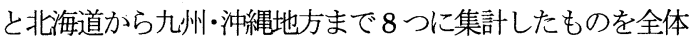
からの比率としてパーセント表示したものである.（合計は 100 パーセント) そのため, 㷌着便益額の合計が負の值とな る場合はマイナスで表示されている. なお, 地域分類につい ては表-5 と同様であり, 沖縄地方だけは九州地方に計上し てある. 帰着便益の割合は全てが正の便益割合である場合, 左端加自地域，北海道，東北，関東，中部，近畿，中国， 四国，九州・沖䋲地方の順に表示してある.

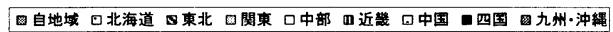

o\% $10 \% \quad 20 \% \quad 30 \% \quad 40 \% \quad 50 \% \quad 60 \% \quad 70 \% \quad 80 \% \quad 90 \% \quad 100 \%$

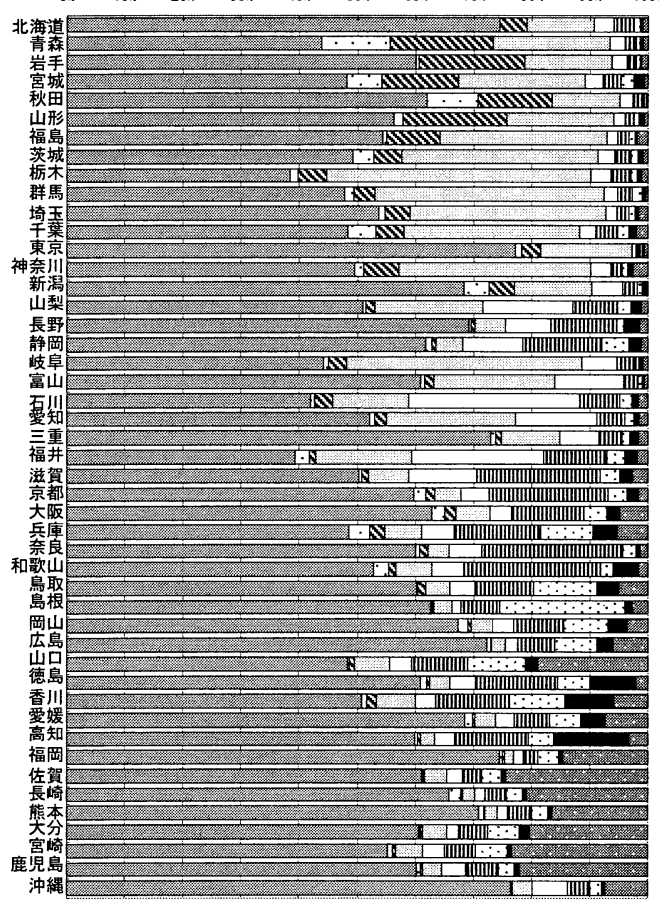

図-1＼cjkstart政策による便益の帰着割合(Case1)

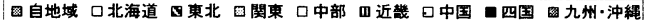

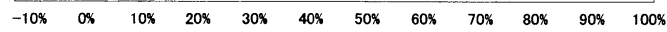

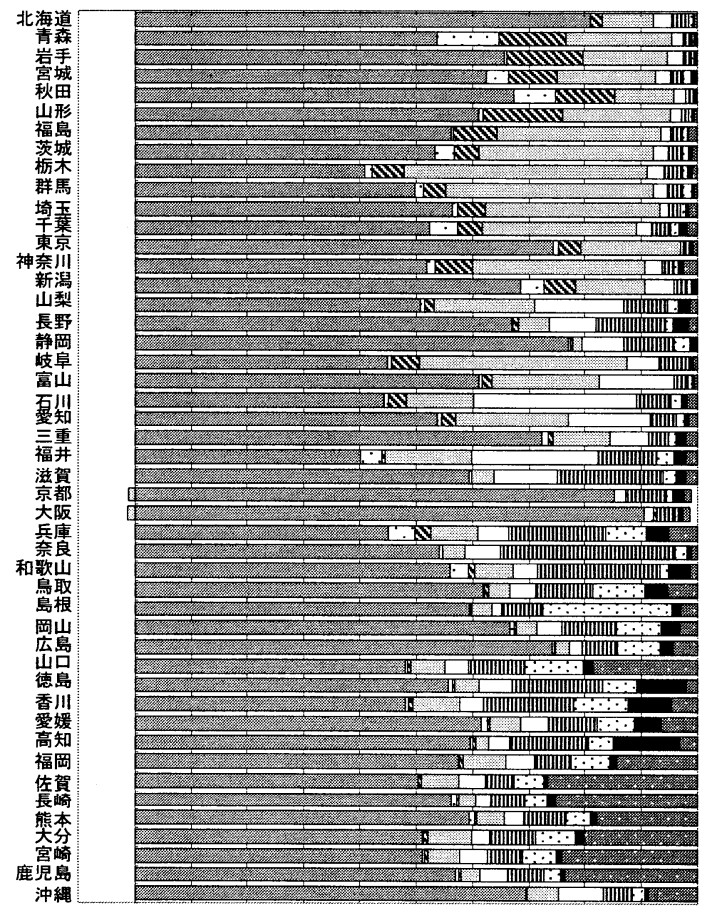

図-2 政策による便益の帰着割合(Case2)

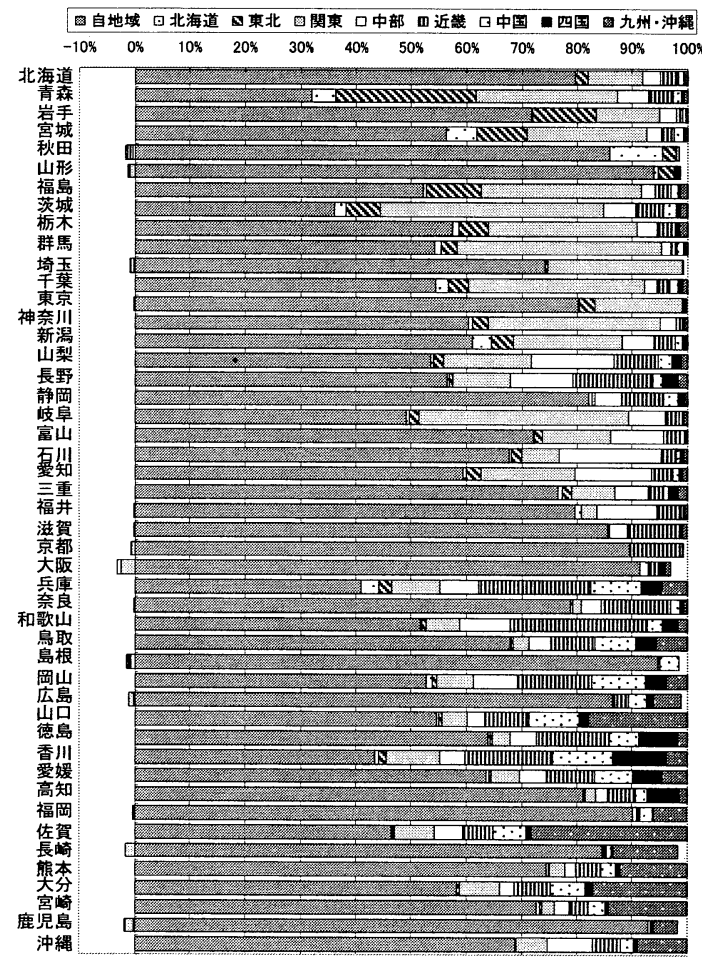

図-3 政策による便益の帰着割合(Case3) 
各ケースを比較すると, 各政策実施都道府県で便益の帰 着構造にはほぼ同じ傾向が見られる. 一方で, 個別の便益 帰着割合についてはCase1 より Case 3 のほうが政策実施 地域への便益帰着割合が大きくなっている. ただし，全体 的な便益の帰着構造については各ケースとも大きな違い が見られなかったので以下では Case3 の結果を用いて考 察を進める.

図-3 を見ると,政策実施都道府県によって便益の帰着構 造が異なることがわかる.これは自地域一の影響比率を見 ても明らかである．政策実施地域が東京の場合は $80 \%$ で あるが鳥取の場合は $68 \%$ といった具合である. Case3 に おいて自地域への影響比率が最も大きかったのは島根 (98\%)，最も小さかったのは青森（32\%）となった。ま た, 他の地方への帰着便益，いわゆる便益のスピルオーバ 一の構造についても政策実施都道府県によって異なり, 負 の便益が見られる場合もある. 政策による負の便益をうけ る地方としては関東地方が多く西日本の地域に政策を実 施したときに見られる. 次に政策による各地方へのスピル オーバーの構造に着目していく.

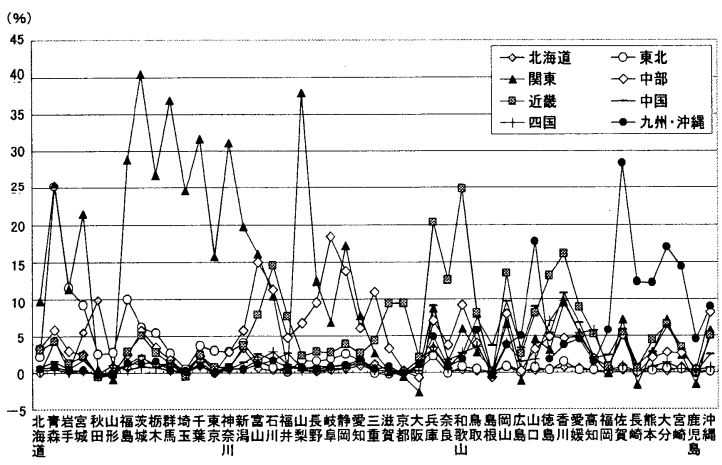

図-4 スピルオーバーの帰着構造(Case3)

図-4 は，図-3 の帰着便益のうち政策実施地域以外への 便益のスピルオーバーだけを取り出したものである. 社会 資本整備による効果は, 地域間交易を通じてその効果が他 の地域に波及するため, スピルオーバーの割合が高い地方 は政策実施地域との地域間交易が盛んであるといえる.

図-4を見ると,スピルオーバーの帰着構造には政策を実 施する地域によって特徵があることがわかる. 北海道から 中部地方までの東日本に政策を実施した場合を見ると，関 東地方へのスピルオーバーの割合が比較的高い地域が多 い. 特に関東地方では, 政策実施都県への帰着割合と合わ せて便益の $80 \%$ 前後が東京周辺の地域に帰着することに なる.これから，東京圈とその周辺地域の交易が盛んであ ることが分かる. また中部地方の中でも岐阜・三重両県に
政策を実施した場合, 中部地方へのスピルオーバーの割合 が高くなっている.これは，隣接する大都市圈である愛知 との交易が盛んであり両県一の政策による愛知一の帰着 便益割合が大きいためである. 次に近畿・中国・四国地方 を見ていくと，両地域とも近畿地方へのスピルオーバーの 割合が他の地域に比べて大きいものの，他の地域へもある 程度の便益のスピルオーバーが見られる. ここから, 西日 本の地域においては近畿地方（特に大阪・兵庫）を中心と した広い範囲の地域において直接的, 間接的な地域間交易 があるといえる. ただし，山口県について九州・沖縄地方 へのスピルオーバーの割合が高いのは地理的関係から九 州地方との地域間交易が盛んなためである. 最後に九州・ 沖縄地方であるが, 政策を実施した場合に周辺地域である 九州・沖縄地方への便益のスピルオーバーの割合が非常に 大きいことから，九州・沖縄地方では他の地方との交易に 比べて地方内での交易が多いことが分かる。

以上, 便益のスピルオーバーの構造から地域ごとの特徵 を見てきたが,このような地域特性の背景には各地域間で の地域間交易の変化に加え，産業構造が大きく影響してい ると考えられる.

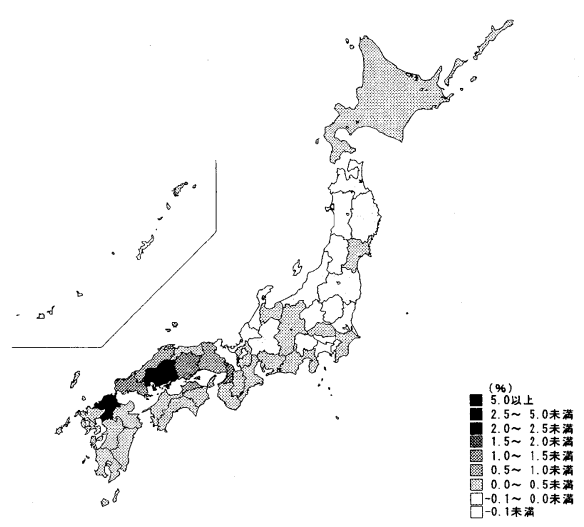

図-5 便益の帰着構造(Case3·広島)

そこで，詳細な分析として，広島を例に挙げて見てい く. 図-5 は，広島へ政策を実施したときの各都道府県の 帰着便益割合を示したものである. 政策実施地域である 広島への帰着便益割合が全体の約 $85 \%$ を占めており，ま た広島を中心とした西日本の各地域に便益が多く帰着 している. 一方，近畿地方以東の地域では非常に帰着便 益の割合が小さいか，あるいはマイナスとなっているこ とが見て分かる. 最終需要量の変化を見ると，広島とそ の周辺地域て製造業, 商業, 運輸・通信業, サービス業 を中心に財の需要量が増加している. 特に大阪・兵庫一 の増加量が大きく，その他西日本の各府県においても広 
島に加え大阪・兵庫からの移入量の増加が見られた. 福 岡への帰着便益の割合が特に大きいのは，直接的な交易 に加え，広島・福岡両県と隣接しており製造業を中心と した交易が盛んな山口を通した間接的な交易量の変化 が大きいためである. 一方, 東日本については生産財価 格の上昇と広島周辺地域内のみでの財の交易量の増加 によって西日本からの財の移入量が低下したことで, 結 果的に便益が負になったといえる.

\section{5. まとめ}

本研究では, 社会資本整備による空間的波及効果を計 測することのできる空間的応用一般均衡モデルを用いて， 各都道府県の社会資本ストックが増加したときの便益の 帰着構造を定量的に把握し, それらを比較することで, 地域社会資本整備の帰着便益の違いを考察した.

その結果, 社会資本整備の空間的波及効果の特徵は都 道府県ごとに大きく異なることがわかった，特に，政策 実施地域への帰着便益の割合は都道府県ごとに大きく異 なっている. 一方, 波及する範囲を地方別で見ることに より各都道府県間の社会経済的な繋がりが把握できた. その成果は，(1)北海道・東北・関東地方は主に関東地方 への帰着便益が大きい. (2)中部地方は中部地方（特に愛 知県) および全国への帰着便益が大きい. (3)近畿・中国・ 四国地方は近畿地方への帰着便益が大きいものの, 全国 一効果が波及している. (4)九州・沖縄地域は主に九州地 方への帰着便益がおおきい:ことがわかった.

このように空間的応用一般均衡分析を社会資本整備評 価に応用することで, 政策実施地域と最終的便益帰着地 域（最終的な便益享受者居住地域）を明確にすることが 可能となる. これらの手法を援用することで, 国土形成 計画などを考える上で，その地域間公平性を考察する十 分な根拠となりえるであろう。一方で手法に関しては, いまいちど, 十分な検証が必要なことはいうまでも無い． 特に以下にあげる事項は，これらの分析がより精緻化す る上で重要な事項である.

(1)地域間所得移転状況の把握

基淮データセットである地域間産業連関表には付加価 值項目の受け取り地域の記載がない.そのため, 実際に は他県に居住している資本あるいは労働の保有者の便益 を正確に把握することが不可能である，また，実物経済 以外の要因による地域的繋がり，すなわち，金融経済に よる地域間の連関関係を把握するデータセットが存在し ないことも地域間所得移転状況を把握すること難しくし ている.

\section{(2)地域選択弾力性の推定}

既存研究 2)でも示されているように, 最終的便益帰着状 況は地域選択の代替弾力性に大きく依存する. わが国で はこの值の実証研究事例が乏しく, 信頼性の面で問題が あるといわれている. 本研究では, 既存研究6の值を用い ているが，それも農林水産業と製造業のみである. より 多くのデータセットからこの值を推計して研究蓄積をす るべきである.

\section{(3)社会資本整備の機能に基づく分析}

本来, 社会資本整備は, その機能により産業の生産効 率性に寄与寸る. 本研究ではその部分を捨象して, 社会 資本ストック額総量が生産効率性に何らかの関連がある として統計的に分析を進めている. そのため, このよう な分析に対する批判は, 総量だけ増やし役に立たない社 会資本整備を行っても社会厚生向上に寄与寸る点である. そのため, 社会資本整備の機能に基づく分析が必要であ る. なお, 当然のことであるが空間的応用一般均衡分析 を用いて交通整供評価を行う場合は, その時間短縮とい う機能に関してモデル化を行っている.

\section{【謝辞】}

匿名の査読者から, 有意義なコメントを頂いた, ここ に記して感謝する. なお, 本稿に関する一切の責任は著 者が負うものである.

\section{【参考文献】}

1）例えば, Mera Koichi : Regional Production Function and social Overhead Capital : An Analyses of the Japanese Case, Regional and Urban Economics, Vol.. 3, No.2,pp.157-186,1973.

2）小池淳司・上田孝行・秋吉盛司 : 社会資本ストック崩 壊による経済的被害の空間的把握一空間的応用一般 均衡モデルによる計量厚生分析一, 土木計画学研究 論文集 Vol.21，No2，pp.367-374，2004.

3）内閣府経済社会総合研究所国民経済計算部編: 県民経 済年報より 1985 年から 1998 年分を使用, 内閣府.

4）電力中央研究所作成: 経済データの開発その1一製造 業資本ストック・社会資本ストックの推計一より 1985 年から 1998 年分を使用, 電力中央研究所.

5）宮城俊彦・石川良平・由利昌平・土谷和之: 地域内産 業連関表を用いた都道府県間産業連関表の作成, 土木 計画学研究・論文集 Vol20, No1, pp87-95, 2003.

6）土谷和之・秋吉盛司・小池淳司 : SCGE モデルにおけ る地域間交易の代替弾力性に関する検討, 応用地域学 会年次講演会, 明海大学, 2005. 

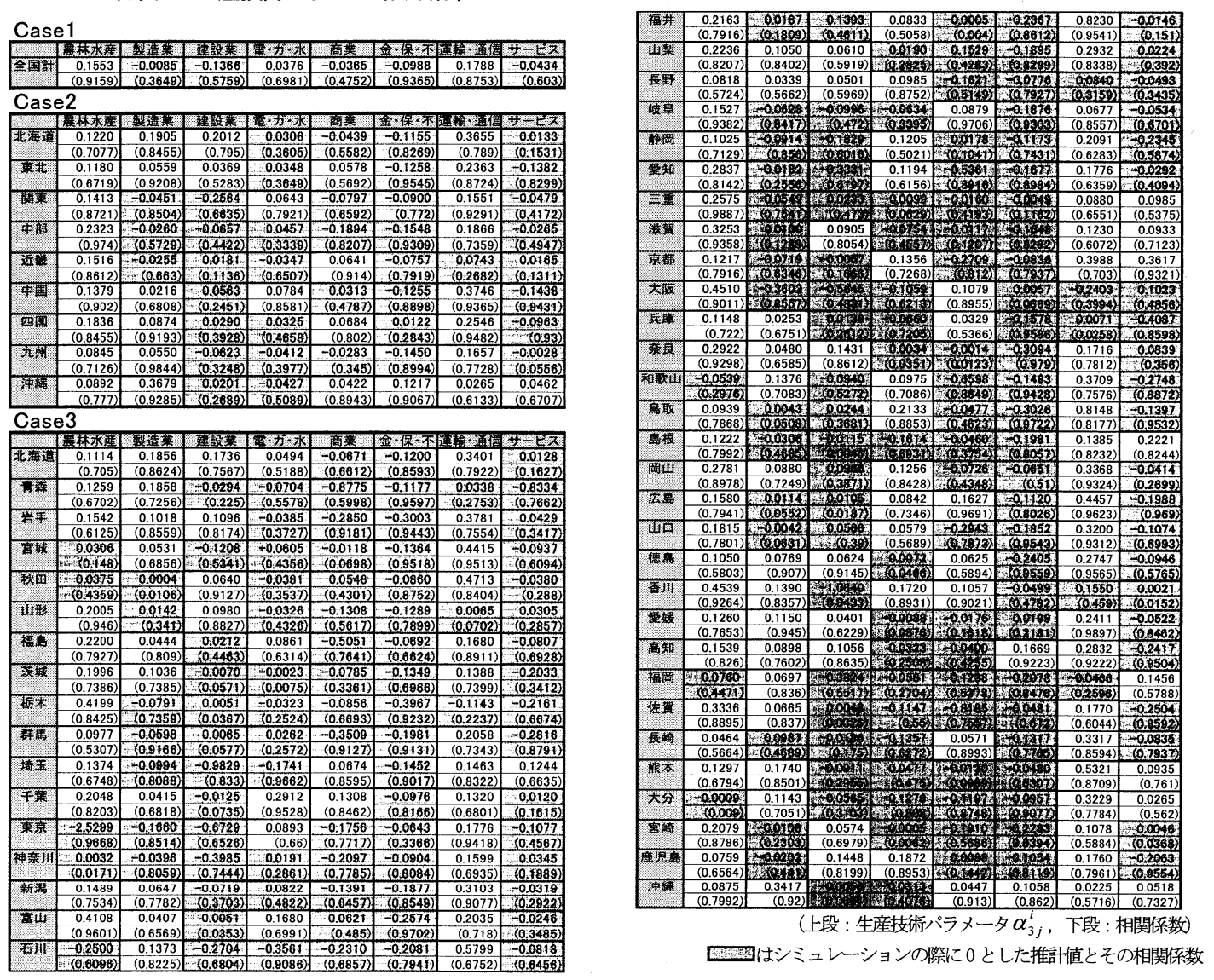

\section{社会資本スピルオーバ一効果の県間比較*}

小池淳司**・西尾明子***

近年わが国では中央・地方政府の慢性的な財政悪化から公共事業の効率化が求められている. より正確な意思決定を行 うためには，費用構造の明確化のみならず，その便益の地域間帰着構造をより正確に把握する必要がある. 本研究では, 社会資本整備による影響を考慮可能な空間的応用一般均衡（SCGE）モデルを用いて，わが国の 47 都道府県ごとに社会 資本整備を行ったとき場合の帰着便益を定量的に計測し，その結果から地域公共事業による便益の空間的構造を分析する. なお, 分析の際には, 社会資本ストックがどの程度生産性に寄与しているかを(1)全国で同じ(2)全国 9 地域ごとに同じ(3)47 都道府県ごとの3つのケースを想定してシミュレーションを行った.

\section{Regional Propagation of the Local Social Capital Investment*}

By Atsushi KOIKE** and Akiko NISHIO***

Recently, society needs more efficient public investment because of the financial difficulty of central and local government. Beside, regional economies through the interregional trade are connecting each other more strongly. To make a plan of the efficient public investment, planner should understand quantitative effect from the regional social capital investment. In this study, we analyze the regional propagation of the social capital investment by spatial computable general equilibrium model. In this analysis, we suppose 3 cases about contribution to Total Factor Productivity of social capital stock and estimate production functions in each case. 